DOI: https://doi.org/10.24144/2409-6857.2018.1(51).381-386

УДК: 368.5

Танклевська Н.С., Ярмоленко В.В.

\title{
ТЕНДЕНЦІЇ РОЗВИТКУ СТРАХУВАННЯ СІЛЬСЬКОГОСПОДАРСЬКИХ КУЛЬТУР В УКРАЇНI
}

\begin{abstract}
Стаття присвячена визначенню сучасних тенденцій розвитку ринку страхування сільськогосподарських культур. Виявлено, щзо ринок агрострахування активно розвивається. Здійснено аналіз функціонування ринку страхування сільськогосподарських культур у період з 2005 по 2017 роки і визначено, що пожвавлення ринку після затяжної кризи почалося в 2016 рочі. Проведена оцінка такого розвитку за показниками: кількість укладених договорів, застрахована площу, страхова сума, страхові премї, страхові ставки та рівень виплат. Визначено, які страхові продукти представлено на сьогоднішній день на ринку агрострахування і на яких умовах.
\end{abstract}

Ключові слова: сільське господарство, страхування, ринок агрострахування, страховий договір, страхові преміі, страхова сума, страхові програми, індексне страхування.

Постановка проблеми. В умовах затяжної політико-економічної кризи девальвація національної валюти, необгрунтованої державної політики та низка інших факторів зумовили порушення ефективної роботи економічної системи України. У зазначених умовах стабілізувати ситуацію можна завдяки розвитку та якісному функціонуванню сільського господарства, що забезпечить вирішення питань підвищення його продовольчої та фінансової безпеки [5]. Сьогодні сільське господарство перспективна галузь розвитку економіки країни. Але в той же час $\epsilon$ однією 3 найбільш ризикованих, оскільки успіх галузі багато в чому залежить від погодних умов. Ціни на продукцію аграріїв постійно зростають, тому втрата або недоотримання врожаю обертаються значними матеріальними збитками для виробників та призводить до втрати вигод. Вступ України до СОТ в 2008 році, запуск зони вільної торгівлі 3 Європейський союзом у 2016 році ставить нові вимоги до продукції сільського господарства, вимагає створення більш конкурентного середовища в країні. Надійний захист товаровиробників продукції сільського господарства від ризиків забезпечує страхування.

Аналіз останніх досліджень і публікацій. Проблеми розвитку страхування сільсько-

(C) Танклевська Наталія Станіславівна, д.е.н., професор, завідувач кафедри економіки та фінансів, ДВНЗ «Херсонський державний агарний університет», м. Херсон, тел.: 0506060622, email: ntanklevska@gmail.com

Ярмоленко Віталіна Вікторівна, аспірантка, асистент кафедри економіки та фінансів, ДВНЗ «Херсонський державний агарний університет», м. Херсон, тел.: 0959382367, email: vitalina.yarmolenko2016@gmail.com господарських культур висвітлено у працях багатьох як українських, так i зарубіжних вчених, зокрема В.Д. Базилевича, К.Г. Воблого, О.С. Гудзь, С.С. Осадця, Б.К. Супіханова, C.А. Навроцького, I.M. Паска, Т.А. Ротової, Н.С. Танклевської, Я.П. Шумелди та інших.

На думку С.С. Осадця, саме страхування продукції рослинництва $€$ актуальним. «Найбільш ризикованим $є$ вирощування врожаю сільськогосподарських культур та багаторічних насаджень. Під це виробництво відведено більш як половину території України. Рослинництво це діяльність, здійснювана переважно під відкритим небом, i на результати господарювання тут істотно впливають коливання кліматичних умов та інші природні чинники, які точно прогнозувати неможливо» [4]. Значний внесок у створення i розвиток аграрного страхового ринку 3 підтримкою держави відводиться Міжнародній фінансовій кооперації (IFC, Група Світового банку). Цей проект передбачає втілення міжнародного досвіду в сфері страхування сільськогосподарських ризиків за різних варіантів участі держави в страхуванні.

Проте 3 часом проявляються нові закономірності та зміни у страхуванні сільськогосподарських культур і тому визначення сучасних тенденцій $€$ актуальним питанням.

Формування цілей статті. Метою статті $є$ визначення сучасних тенденцій розвитку ринку страхування сільськогосподарських культур та аналіз доступних страхових продуктів.

Для досягнення поставленої мети вирішені такі завдання:

- здійснено аналіз основних показників розвитку сучасного ринку сільськогосподарського страхування рослинництва. 
- виявлені доступні страхові продукти, які представлені на ринку агрострахування на сьогоднішній день.

Опис основного матеріалу дослідження. Ринок агрострахування в Україні почав активно розвиватися на початку 2000 -х років.

За ці 17 років Україна двічі намагалася запровадити систему державної підтримки, що напряму відбилося на збільшенні показників ринку страхування сільського господарства.
Проаналізувавши тенденції розвитку ринку страхування аграрних ризиків у період з 2005 по 2017 рік, можна зробити висновок, що 2016 рік став першим роком пожвавлення після тривалого застою.

В 2017 році динаміка зростання поширилась на більшу кількість показників. Тенденції розвитку ринку агрострахування можна прослідкувати за даними таблиці 1 i на рисунках $1-2$.

Таблиця 1

\begin{tabular}{|c|c|c|c|c|c|c|c|c|c|c|c|c|c|c|}
\hline \multicolumn{15}{|c|}{ Страхування сільськогосподарських культур у 2005-2017 роках * } \\
\hline Показник & 2005 & 2006 & 2007 & 2008 & 2009 & 2010 & 2011 & 2012 & 2013 & 2014 & 2015 & 2016 & 2017 & $\begin{array}{c}\text { Т зр. } \\
2017 \mathrm{p} . \\
\text { до } \\
2014 \mathrm{p} . \\
(\%)\end{array}$ \\
\hline $\begin{array}{l}\text { Кількість } \\
\text { договорів }\end{array}$ & 910 & 1330 & 4397 & 1637 & 1980 & 1217 & 2710 & 1936 & 1722 & 1392 & 1062 & 793 & 957 & 68,75 \\
\hline $\begin{array}{l}\text { Площа, } \\
\text { тис.га }\end{array}$ & 390 & 670 & 2360 & 1171 & 510 & 553 & 786 & 727 & 869 & 732 & 689 & 700 & 657 & 89,75 \\
\hline $\begin{array}{l}\text { Страхова } \\
\text { сума, млн } \\
\text { грн }\end{array}$ & н/д & н/д & н/д & н/д & н/д & н/д & н/д & н/д & н/д & 3055 & 3969 & 6240 & 5913 & 193,55 \\
\hline $\begin{array}{l}\text { Страхові } \\
\text { премії, } \\
\text { млн грн }\end{array}$ & 12,8 & 28,5 & 116,7 & 155,4 & 42,0 & 72,1 & 136,3 & 130,4 & 135,4 & 72,8 & 77,7 & 157 & 204,4 & 280,77 \\
\hline $\begin{array}{l}\text { Субсидія, } \\
\text { млн грн }\end{array}$ & 5,8 & 12,5 & 47,8 & 72,8 & 0 & 0 & 0 & 0,086 & 0 & 0 & 0 & 0 & 0 & \\
\hline $\begin{array}{l}\text { Рівень } \\
\text { виплат }\end{array}$ & н/д & н/д & н/д & н/д & $\begin{array}{c}36,50 \\
\%\end{array}$ & $\begin{array}{c}50,90 \\
\%\end{array}$ & $\begin{array}{c}28,00 \\
\%\end{array}$ & $\begin{array}{c}41,00 \\
\%\end{array}$ & $\begin{array}{c}9,70 \\
\%\end{array}$ & $\begin{array}{c}7,60 \\
\%\end{array}$ & $\begin{array}{c}12,90 \\
\%\end{array}$ & $\begin{array}{c}44,20 \\
\%\end{array}$ & $\begin{array}{l}3,7 \\
\%^{2}\end{array}$ & \\
\hline $\begin{array}{l}\text { Середня } \\
\text { ставка } \\
\text { премії }\end{array}$ & $\begin{array}{c}3,80 \\
\%\end{array}$ & н/д & $\begin{array}{c}4,50 \\
\%\end{array}$ & $\begin{array}{c}4,90 \\
\%\end{array}$ & $\begin{array}{c}3,20 \\
\%\end{array}$ & $\begin{array}{c}3,80 \\
\%\end{array}$ & $\begin{array}{c}3,70 \\
\%\end{array}$ & $\begin{array}{c}3,80 \\
\%\end{array}$ & $\begin{array}{c}3,10 \\
\%\end{array}$ & $\begin{array}{c}2,40 \\
\%\end{array}$ & $\begin{array}{c}2,00 \\
\%\end{array}$ & $\begin{array}{c}2,50 \\
\%\end{array}$ & $\begin{array}{c}3,50 \\
\%\end{array}$ & 145,83 \\
\hline $\begin{array}{l}\text { Сума } \\
\text { премій, } \\
\text { млн \$ }\end{array}$ & 2,5 & 5,6 & 23,1 & 29,8 & 5,3 & 9,1 & 17,1 & 16,3 & 16,9 & 5,6 & 3,4 & 6,0 & 7,7 & 137,50 \\
\hline
\end{tabular}

* Розраховано авторами за даними [2]

Так, порівняно з 2016 роком кількість укладених договорів зросла на 164 договори, що становить $21 \%$. У 2017 році було укладено 427 договорів - на зимовий та 530 - на весняно- літній період. Обсяг зібраних страхових премій у гривні зростає вже третій рік поспіль, зокрема, у 2017-му році він зріс на $30 \%$ та склав 204.4 млн грн.

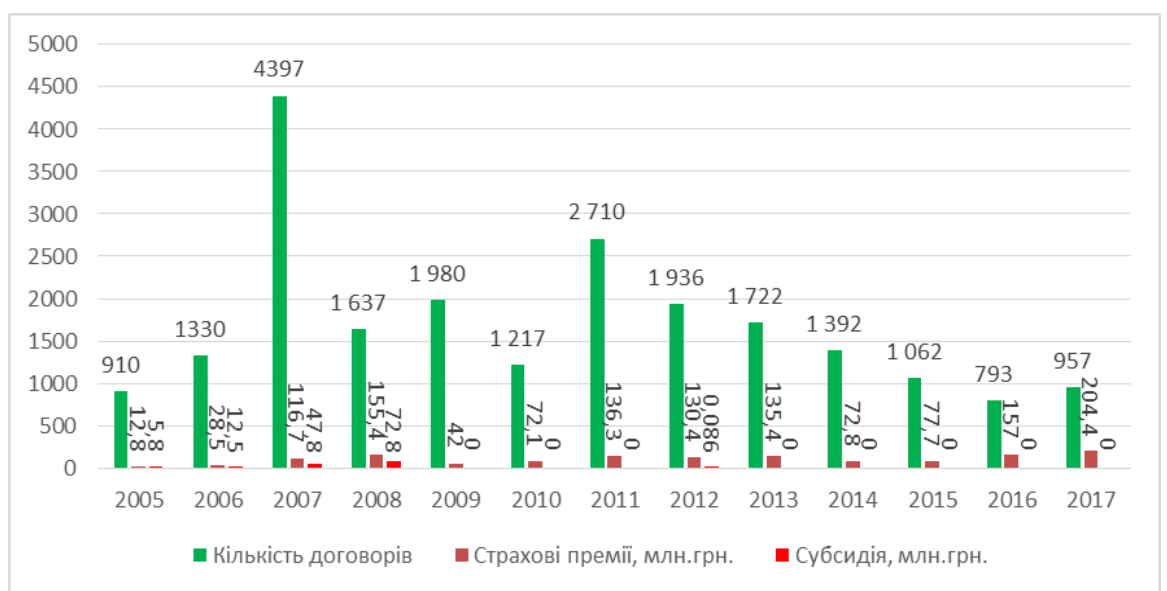

Рис.1. Тенденції ринку страхування сільського господарства за 2005-2017 роки *

* Сформовано авторами за даними [2] 


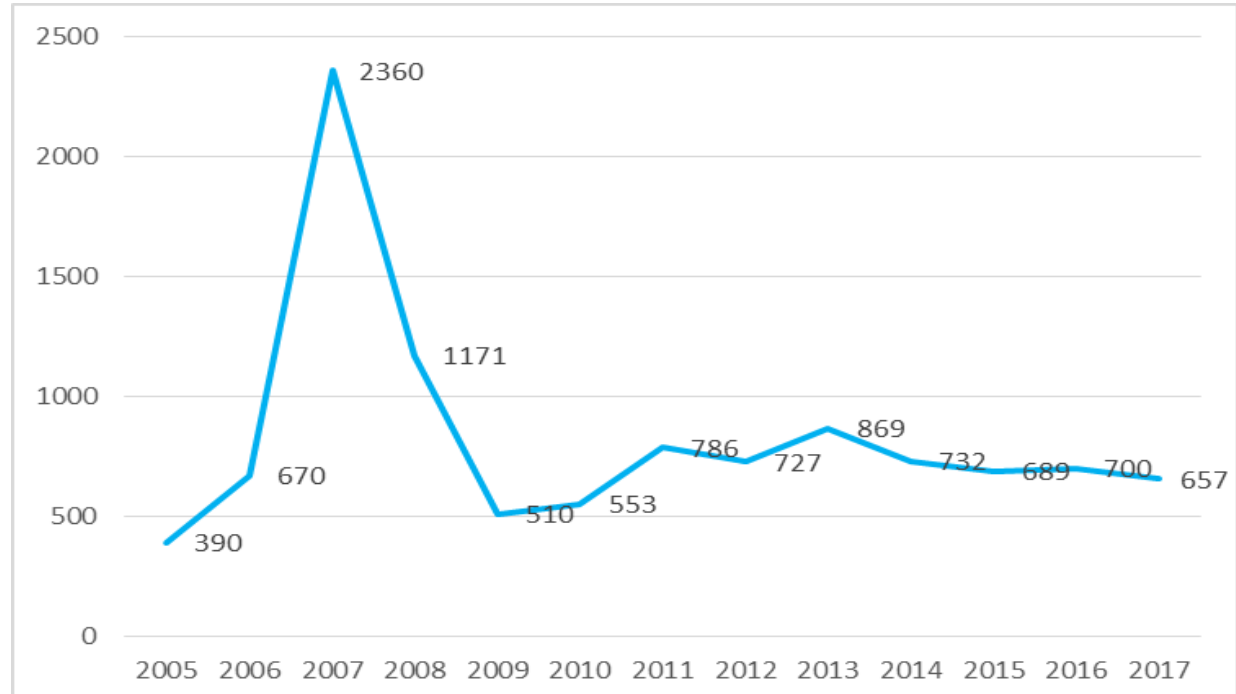

Рис. 2. Динаміка застрахованої площі у 2005-2017 рр., тис. га*

\section{* Сформовано авторами за даними [2]}

Також у 2017 році збільшився обсяг страхових премій у доларовому еквіваленті. У 2017 році він складав 7,7 млн дол., що на 28\% більше, ніж у 2016 році. Загальна страхова сума у 2016 році була більшою на 327 млрд грн ніж у 2017 [2]. Найбільшу кількість договорів було укладено у Тернопільській (98) та Дніпропетровській (94) областях. За показником застрахованої площі першість належить Полтавській (75,6 тис. га) та Хмельницькій $(75,3$ тис. га) областям. У таблиці 2 наведені дані страхування у розрізі областей.

Таблиця 2

Дані страхування в розрізі областей, 2017 р. [2]

\begin{tabular}{|l|c|c|c|c|c|c|}
\hline \multicolumn{1}{|c|}{ Область } & $\begin{array}{c}\text { Кількість } \\
\text { договорів }\end{array}$ & $\begin{array}{c}\text { Площа, } \\
\text { га }\end{array}$ & $\begin{array}{c}\text { Страхова } \\
\text { сума, грн }\end{array}$ & $\begin{array}{c}\text { Сума премій, } \\
\text { грн }\end{array}$ & $\begin{array}{c}\text { Середня } \\
\text { ставка премії }\end{array}$ & $\begin{array}{c}\text { Сума } \\
\text { премій, } \\
\text { грн/га }\end{array}$ \\
\hline АР Крим & 0 & 0 & 0 & 0 & 0 & 0 \\
\hline Вінницька & 55 & 17,730 & $240,054,159$ & $9,504,101$ & $4.0 \%$ & 536 \\
\hline Волинська & 10 & 2,225 & $23,098,100$ & 805,192 & $3.5 \%$ & 362 \\
\hline Дніпропетровська & 94 & 67,343 & $588,701,087$ & $18,087,414$ & $3.1 \%$ & 269 \\
\hline Донецька & 15 & 7,709 & $43,177,595$ & 906,326 & $2.1 \%$ & 118 \\
\hline Житомирська & 47 & 11,888 & $116,802,143$ & $3,706,853$ & $3.2 \%$ & 312 \\
\hline Закарпатська & 3 & 573 & $2,178,592$ & 90,691 & $4.2 \%$ & 158 \\
\hline Запорізька & 31 & 11,914 & $81,138,885$ & $3,161,282$ & $3.9 \%$ & 265 \\
\hline Івано- & 20 & 19,857 & $170,691,572$ & $4,595,453$ & $2.7 \%$ & 231 \\
Франківська & 34 & 8,792 & $70,436,055$ & $2,631,687$ & $3.7 \%$ & 299 \\
\hline Київська & 55 & 27,222 & $164,257,088$ & $4,241,486$ & $2.6 \%$ & 156 \\
\hline Кіровоградська & 7 & 3,620 & $40,061,879$ & $1,708,338$ & $4.3 \%$ & 472 \\
\hline Луганська & 25 & 13,570 & $174,362,176$ & $6,499,652$ & $3.7 \%$ & 479 \\
\hline Львівська & 23 & 24,204 & $275,635,044$ & $12,526,133$ & $4.5 \%$ & 518 \\
\hline Миколаївська & 9 & 7,831 & $19,243,961$ & 808,106 & $4.2 \%$ & 103 \\
\hline Одеська & 75 & 75,645 & $771,680,987$ & $33,713,141$ & $4.4 \%$ & 446 \\
\hline Полтавська & 21 & 13,873 & $322,457,325$ & $14,807,476$ & $4.6 \%$ & 1,067 \\
\hline Рівненська & 43 & 46,959 & $623,807,675$ & $17,765,292$ & $2.8 \%$ & 378 \\
\hline Сумська & 98 & 39,365 & $300,122,758$ & $7,917,288$ & $2.6 \%$ & 201 \\
\hline Тернопільська & 46 & 57,460 & $165,196,591$ & $5,061,456$ & $3.1 \%$ & 88 \\
\hline Харківська & 54 & 37,398 & $359,408,559$ & $15,925,942$ & $4.4 \%$ & 426 \\
\hline Херсонська & 68 & 75,326 & $497,094,091$ & $15,594,123$ & $3.1 \%$ & 207 \\
\hline Хмельницька & 42 & 27,178 & $380,232,455$ & $11,474,045$ & $3.0 \%$ & 422 \\
\hline Черкаська & 16 & 11,439 & $163,638,437$ & $4,607,752$ & $2.8 \%$ & 403 \\
\hline Чернівецька & 66 & 48,023 & $319,888,911$ & $8,307,642$ & $2.6 \%$ & 173 \\
\hline Чернігівська & & & & & & \\
\hline
\end{tabular}


За об’ємом зібраних премій області України розташувалися в такому порядку: Полтавська (33.7 млн грн, або 16.5\%), Дніпропетровська (18.1 млн грн, або 8.8\%), Сумська (17.8 млн грн, або 8.7\%), Херсонська (15.9 млн грн, або 7.8\%), Хмельницька (15.6 млн грн, або 7.6\%),
Рівненська (14.8 млн грн, або $7.2 \%)$, Миколаївська (12.5 млн грн, або 6.1\%) та Черкаська (11.5 млн грн, або 5.6\%) [2]. На рисунку 3 відображено стан страхування сільськогосподарських культур у розрізі областей.

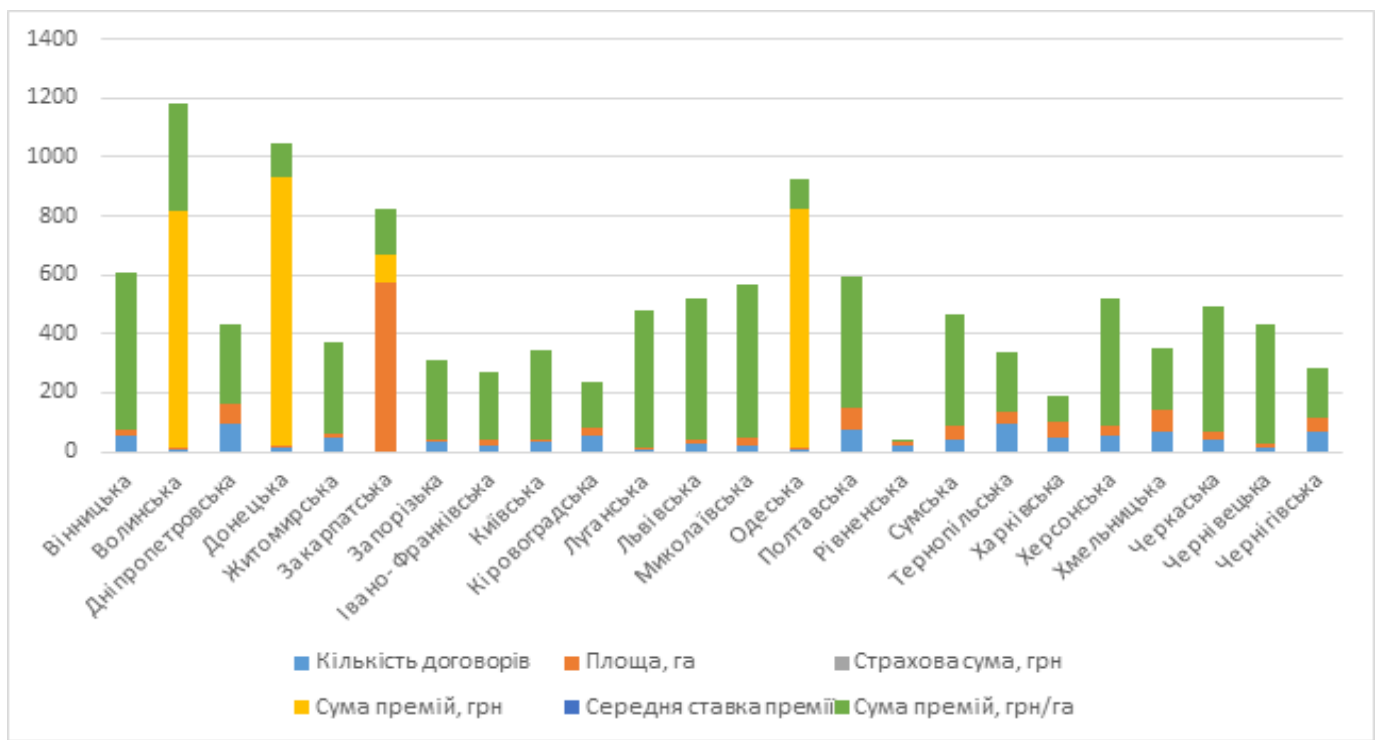

*Розроблено авторами

Рис. 3. Зведена діаграма страхування в розрізі областей*

Експерти дають прогнози зростання ринку страхування сільського господарства і в 2018 році. Це зумовлено збільшенням ризиків, які пов'язані 3 погодними умовами. Раніше страхували в основному озимі від пошкодження морозами, а сьогодні постає загроза від весняних заморозків. Метеорологи прогнозують більш жорсткіші умови господарювання для аграріїв, тому зростає потреба захисту в страхуванні. Проте існують проблеми, які гальмують агрострахування. Одна 3 основних причин взаємна недовіра аграрних товаровиробників i фінансових компаній, які займаються страхуванням сільськогосподарських ризиків.

Аграрії не вірять, що отримають компенсацію в разі настання страхового випадку, а страхові компанії, в свою чергу, не знають як працювати 3 аграрним сектором, вони не впевнені, що можуть оцінити всі можливі ризики. Спростити комунікацію між сторонами може використання прозорих доступних страхових продуктів.

У 2016 році Проектом Міжнародної фінансової корпорації (IFC) спільно 3 компаніямипартнерами - «Сингента», Креді Агріколь Банк, «AXА Страхування» була запроваджена комплексна програма для агробізнесу «Ваш урожай - наша турбота». Дана програма розрахована на три роки. В рамках цієї програми був представлений інноваційний страховий продукт для страхування посівів та майбутнього врожаю озимої пшениці. Він розрахований передусім на малих та середніх агровиробників, які обмежені в фінансуванні. Цей продукт прив'язаний до фінансування 3 боку Креді Агріколь Банк та отримання товарних кредитів від компанії «Сингента». Таким чином, продукт зорієнтований на чинних та потенційних клієнтів цих компаній.

Страховка озимої пшениці на весь період вирощування включається 3 моменту, коли представники страхової компанії виїхали в поля, зафіксували якість сходів та агровиробник сплатив свою частину страхового платежу. Страховий продукт надає страхове покриття, яке складається 3 двох фаз із відповідною виплатою відшкодування після кожної фази. Перша фаза це зимові ризики, друга - це весняно-літні ризики. Основною перевагою першої фази є те, що рівень покриття площі під культурою складає $95 \%$. Це найвищий показник, доступний на ринку на сьогоднішній день. Страхові компанії стандартно пропонують страховий захист на рівні 70\% від страхової суми. Друга перевага полягає у врегулюванні страхових випадків та здійсненні виплати за кожен загиблий гектар площі культури. Друга фаза (після відновлення вегетації) передбачає страхування майбутнього врожаю. Рівень страхового покриття в цьому випадку дорівнює 70\% від середньої врожайності озимої пшениці в господарстві за останні три 
роки. Новація даного продукту полягає в тому, що страхування покриває не лише витрати, які пішли на посів, а й частину планових витрат на вирощування та збирання врожаю.

Нині не тільки в Україні, а й в цілому світі набирає популярності індексне страхування. Воно не потребує виїзду інспектора для встановлення страхового випадку. Плюси такого підходу є очевидними: простота, дешевизна i швидке отримання виплати. Це прозорий i зрозумілий метод страхування. Існує багато різновидів індексних страхових продуктів. Зокрема, можна виділити погодні та «врожайні» [6]. Індексне страхування передбачає право страхувальника на відшкодування в тому випадку, якщо врожайність застрахованої ним культури впаде нижче гарантованого рівня. Індексне страхування здійснюється від тих погодних ризиків, які вимірюються певними параметрами. Тому вони обмежені температурою, опадами, силою вітру, товщину снігового покриву тощо. А от град до цього переліку не потрапляє. Індексом можна застрахувати осінню посуху, неможливість розпочати посів через відсутність опадів чи їхню надмірність. На відміну від традиційного страхування індексне не передбачає обов'язкового передстрахового огляду посівів та оцінки понесеного господарством збитку.

Висновки i перспективи подальших досліджень. Отже, враховуючи те, що сільське господарство $\epsilon$ високо ризикованим, питання використання страхування сільськогосподарських культур, як методу зменшення майбутніх втрат вигод, $€$ актуальним та своєчасним.

Основними тенденціями розвитку страхування сільськогосподарських культур за останні роки є збільшення на $21 \%$ укладених договорів та на 30\% збільшились страхові преміі в млн грн. Застрахована площа і страхова сума в млн грн. зменшились на 6\% і $5 \%$ відповідно. Після кризи 2014 року почала зростати середня ставка премій в середньому на $42 \%$ за рік і в 2017 році вона складає 3,5 \%. Одним 3 найбільш продуктивних років по рівню страхових виплат був 2016 рік (44,2\%).

Крім цього прослідковується активність міжнародних компаній щодо впровадження страхових програм для аграріїв. Таким чином, на сьогодні ринок страхування сільського господарства активно розвивається. Страхові компанії пропонують нові вигідні для аграріїв програми страхування, які враховують всі більш широкий спектр ризиків.

Перспективи майбутніх досліджень полягають у необхідності здійснення прогнозів щодо подальшого страхування сільськогосподарських культур, а також визначення найбільш ефективних страхових продуктів для аграрних підприємств.

\section{ПЕРЕЛІК ВИКОРИСТАНИХ ДЖЕРЕЛ}

1. Воблый К. Г. Основы экономии страхования / К. Г. Воблый. - Тернопіль : Економічна думка, 2001. $238 \mathrm{c}$.

2. Проект «Розвиток фінансування аграрного сектору в Європі та Центральній Азії», Міжнародна фінансова корпорація (IFC, Група Світового банку), у співпраці з Міністерством аграрної політики та продовольства України [Електронний ресурс]. - Режим доступу: https://forinsurer.com/files/file00624.pdf

3. Страхування : підручник / за ред. В. Д. Базилевича. - К. : Знання, 2008. - 1019 с.

4. Осадець С.С. Підручник / Керівник авт. колективу і наук. ред. С.С.Осадець. - Вид. 2-ге, перероб. і доп. — К.: КНЕУ, 2002. - 599 c.

5. Танклевська Н.С. Основи формування фінансової безпеки функціонування сільського господарства як базису економічного розвитку країни / Науковий вісник НУБІП України. Серія: економіка, аграрний менеджмент, бізнес. м. Київ - 2015 р. - Вип. 222 - С. 15-20

6. Танклевська Н.С. Зарубіжний досвід фінансово-кредитного забезпечення розвитку агарних підприємств / Вісник Агарної науки Причорномор'я. - Вип. 1 (44) - 2008 р. - С. 81-87

7. Тимошенко I. Некомерційні форми страхування : європейський досвід / Вісник Київського національного торгово-економічного університету. - 2015. - № 2. - С. 119-132.

8. Шумелда Я. П. Страхування : навч. посібник / Я. П. Шумелда. - Тернопіль: Джура, 2006. - 249 с.

\section{REFERENCES}

1. Voblyi, K. (2001) Osnovyi ekonomii strahovaniya [Basics of economyt insurance], Ekonomichna dumka, Ternopil, Ukraine [in Russian].

2. Proekt «Rozvytok finansuvannia ahrarnoho sektoru v Yevropi ta Tsentralnii Azii», Mizhnarodna finansova korporatsiia (IFC, Hrupa Svitovoho banku), u spivpratsi z Ministerstvom ahrarnoi polityky ta prodovolstva Ukrainy. Retrieved from https://forinsurer.com/files/file00624.pdf [in Ukrainian]

3. Bazylevych, V. D. ed. (2008) Strakhuvannia [Insurance], Znannia, Kyiv, Ukraine [in Ukrainian].

4. Osadets, S. S ed. (2002), Strakhuvannia [Insurance], 2nd ed, KNEU, Kyiv, Ukraine [in Ukrainian]. 
5. Tanklevska, N. S. (2015). Osnovy formuvannya finansovoyi bezpeky funktsionuvannya sil's'koho hospodarstva yak bazysu ekonomichnoho rozvytku krayiny [Fundamentals of the financial security of the functioning of agriculture as a basis for economic development of the country] Naukovyy visnyk NUBIP Ukrayiny. Seriya: ekonomika, ahrarnyy menedzhment, biznes, 222,15-20 [in Ukrainian].

6. Tanklevska, N. S. (2008). Zarubizhnyy dosvid finansovo-kredytnoho zabezpechennya rozvytku aharnykh pidpryyemstv [Foreign experience of financial and credit support for the development of agrarian enterprises] Visnyk Aharnoyi nauky Prychornomor"ya, 1(44), 81-87 [in Ukrainian].

7. Tymoshenko, I. (2015), Nonprofit insurance forms: European experience. Herald of KNUTE, no. 2, pp. 119-132 [in Ukrainian].

8. Shumelda, Ia. (2004), Strakhuvannia [Insurance], Dzhura, Ternopil, Ukraine [in Ukrainian].

Одержано 15.03. 2018 p. 